\title{
An Evaluation of the Psychosocial Status of Infertile Women
}

\author{
Ferhat Ekinci, ${ }^{1}$ Bige Tuncel, ${ }^{2}$ Arzu Uzuner, ${ }^{3}$ Ali Doğukan Anğın, ${ }^{4}$ \\ Demet Merder Çoşkun, ${ }^{5}$ Önder Sakin, ${ }^{4}$ \\ Muzaffer Seyhan Çıkman, ${ }^{4}$ Engin Ersin Şimşek ${ }^{6}$
}

\author{
'Department of Public Health \\ Directory, Bursa, Turkey \\ 2Department of Family Medicine \\ iliç State Hospital, Erzincan, Turkey \\ ${ }^{3}$ Department of Family Medicine, \\ Marmara University Pendik Training \\ and Training Hospital, \\ Istanbul, Turkey \\ ${ }^{4}$ Department of Obstetrics and \\ Gynecology, Kartal Dr. Lütfi Kırdar \\ Kartal Training and Research \\ Hospital, Istanbul, Turkey \\ ${ }^{5}$ Department of Family Medicine, \\ Gevaş State Hospital, Van, Turkey \\ ${ }^{6}$ Department of Family Medicine, \\ Kartal Dr. Lütfi Kırdar Kartal \\ Training and Research Hospital, \\ İstanbul, Turkey \\ Submitted: 06.12.2017 \\ Accepted: 19.12.2017 \\ Correspondence: Ali Doğukan Anğın, \\ Kadın Hastalıkları ve Doğum Kliniği, \\ Kartal Dr. Lütfi Kırdar Eğitim ve \\ Araştırma Hastanesi, Istanbul, Turkey \\ E-mail:ala_2001@hotmail.com

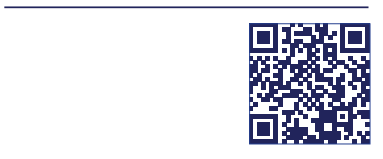 \\ Keywords: Anxiety; \\ depression; infertility; \\ loneliness; social support.
}

\begin{abstract}
Objective: The aim of this study was to evaluate depression, anxiety, loneliness, and the effects of social support in infertile women in Turkey.
\end{abstract}

Methods: A total of I 40 patients who presented at the infertility clinic between June 2012 and December 2012 were included in the study. All of the participants completed the Hamilton Anxiety Rating Scale, the Beck Depression Inventory, the University of California Los Angeles Loneliness Scale, and the Multidimensional Scale of Perceived Social Support.

Results: The depression score of the infertile women was lower than that of the general population, and the anxiety score was found to be similar to that of the general population. The loneliness scale score decreased with additional years of marriage and greater monthly income $(p<0.05 ; p<0.05)$. The social support score also increased with the length of marriage $(p<0.05)$. Two patients were referred to the psychiatry clinic based on the results of the depression scale, and 4 participants were referred based on their anxiety scale scores.

Conclusion: Financial circumstances, duration of marriage, and social support influence depression, anxiety, and loneliness in infertile patients. Since there was no significant difference in the level of depression or anxiety in this group of patients, it was concluded that professional support and treatment are only necessary when appropriate.

\section{INTRODUCTION}

Infertility is a health problem that continues to be important and is seen in about $10 \%$ of couples in society. ${ }^{[1]}$ Depression and anxiety are also important current health problems. There has been an increase in the incidence of depression in recent years, and it is seen as a global health problem. ${ }^{[2]}$ While the association of depression, anxiety, and infertility has been the subject of research for many years, the relationship is still studied. ${ }^{[3-7]}$
In addition, other social problems may play a role in infertility. ${ }^{[8-12]}$ The feeling of loneliness is considered an important problem in psychiatry. Social isolation can lead to social communication problems, serious physical health disorders, and mortality. ${ }^{[8]}$ It has also been expressed in recent publications that loneliness may have increased, especially in women with primary infertility. ${ }^{[9]}$

Women with fertility problems may at times also feel unworthy or guilty. Social support from family, friends, or 
others can be very helpful. Research also indicates that social support is important in decreasing anxiety and desperation. ${ }^{[10]}$ Feelings of depression, anxiety, and loneliness in those with infertility are still being investigated. The relationship has not yet become clear. For example, there are regional differences and these lead to changes in the approach to the patient. [" ${ }^{[1]}$

The aim of this study was to examine the effects of social support, social differences, and personal changes on depression, anxiety, and loneliness in infertile women in this society.

\section{MATERIAL AND METHODS}

In all, 140 infertile patients who presented at the hospital infertility polyclinic between June 2012 and December 2012 were included in the study. The patients completed the Hamilton Anxiety Rating Scale (HAM-A), the Beck Depression Inventory (BDI), the University of California Los Angeles (UCLA) Loneliness Scale, and the Multidimensional Scale of Perceived Social Support (MSPSS) during face-to-face interviews with an investigator who was not involved in the participants' treatment. All of the scales were examined in the presence of an experienced psychiatrist and the results were evaluated.

The BDI is a 21 -item assessment first created in 1961. It was adapted for Turkish society in 1988. It evaluates the physical, emotional, and cognitive symptoms of the patients. Each item on the scale is scored between 0 and 3 . It has been established that a score of 17 or more a depression can be diagnosed with an accuracy of $90 \%{ }^{[10]}$

The HAM-A contains 14 questions; each is answered on a 5 -point scale.

A score below 6 indicates no anxiety. Scores between 6 and 14 signify mild anxiety, and a score above 14 denotes high anxiety. ${ }^{[12]}$

The MSPSS has 3 subscales consisting of a total of 12 questions. The subscales indicate the participants' perceptions related to the support provided by their family, friends, and others. A high MSPSS score suggests a high level of social support. The cutoff value is the mean score of the population who responded. ${ }^{[10]}$

The UCLA Loneliness Scale contains 20 questions; 10 negative and 10 positive questions, with a total score of between 20 and 80 . The feeling of loneliness is greater in correlation with a higher score. ${ }^{[9]}$

The data were analyzed using IBM SPSS Statistics for Windows, Version 20.0 (IBM Corp., Armonk, NY, USA). The statistical analysis was carried out using the Kruskal-Wallis, Mann-Whitney $U$ test, and a chi-square test. A value of $p<0.05$ was considered statistically significant.

\section{RESULTS}

There were 140 infertile women who agreed to participate in the study. The participants' mean age was $28.8 \pm 4.7$ years, the median duration of marriage was 5.7 years, and the median length of infertility was 4.2 years. The infertility of the participants was $79 \%$ primary and $21 \%$ secondary. Of the participants, $49.6 \%$ had previously been treated for infertility. The characteristics of the participants are summarized in Table I.

The depression rate of the patients was found to be lower than that seen in the general population, according to the BDI results. The HAM-A indicated an anxiety level similar to the general population. The UCLA loneliness score of patients who lived with their husband's family was significantly higher than that of those who lived with just their

Table I. Participant characteristics $(n=\mid 40)$

\begin{tabular}{lc}
\hline Characteristics & $\mathbf{n}(\%)$ \\
\hline $\begin{array}{l}\text { Employment status } \\
\quad \text { Not working (housewife) }\end{array}$ & $117(83.7)$ \\
$\begin{array}{l}\text { Smoker } \\
\quad \text { Yes }\end{array}$ & 31 (22.0) \\
Members of household & \\
$\quad$ Husband's family & $32(22.7)$ \\
Those unsympathetic to the participants & \\
because of their infertility & $10(7.0)$ \\
$\quad$ Husband & $18(13.0)$ \\
$\quad$ Husband's family & $128(92.0)$ \\
Sharing with friends & $28.8 \pm 4.7$ \\
Age (years; mean) & 5.7 \\
Duration of marriage (years; median) & 4.2 \\
\hline \begin{tabular}{l} 
Duration of infertility (years; median) \\
\hline
\end{tabular}
\end{tabular}

Table 2. The mean MSPSS and loneliness scores and percentage over mean

\begin{tabular}{lcc}
\hline Scales & Mean \pm SD & \% over mean \\
\hline MSPSS & & \\
MSPSS family & $24.22 \pm 5.3$ & 65.0 \\
MSPSS friend & $19.95 \pm 7.9$ & 57.1 \\
MSPSS other & $19.06 \pm 7.9$ & 55 \\
MSPSS total & $63.25 \pm 15.5$ & 55 \\
UCLA Loneliness Scale & $35.73 \pm 8.5$ & 37.9 \\
\hline
\end{tabular}

MSPSS: Multidimensional Scale of Perceived Social Support; SD: Standard deviation. 
Table 3. Correlation between scales

\begin{tabular}{|c|c|c|c|c|c|}
\hline & Correlation & $\begin{array}{l}\text { Beck Depression } \\
\text { Inventory }\end{array}$ & $\begin{array}{c}\text { Hamilton } \\
\text { Anxiety Scale }\end{array}$ & MSPSS & $\begin{array}{l}\text { UCLA Loneliness } \\
\text { Scale }\end{array}$ \\
\hline \multirow[t]{3}{*}{ Beck Depression Inventory } & Pearson correlation & 1 & & & \\
\hline & Sig. (2-tailed) & & & & \\
\hline & $\mathrm{N}$ & 140 & & & \\
\hline \multirow[t]{3}{*}{ Hamilton Anxiety Scale } & Pearson correlation & .801 & I & & \\
\hline & Sig. (2-tailed) & .000 & & & \\
\hline & $\mathrm{N}$ & 140 & 140 & & \\
\hline \multirow[t]{3}{*}{ MSPSS } & Pearson correlation & -.167 & -.184 & 1 & \\
\hline & Sig. (2-tailed) & .048 & .029 & & \\
\hline & $\mathrm{N}$ & 140 & 140 & 140 & \\
\hline \multirow[t]{3}{*}{ UCLA Loneliness Scale } & Pearson correlation & .453 & .454 & -.587 & I \\
\hline & Sig. (2-tailed) & .000 & .000 & .000 & \\
\hline & $\mathrm{N}$ & 140 & 140 & 140 & 140 \\
\hline
\end{tabular}

MSPSS: Multidimensional Scale of Perceived Social Support; UCLA: University of California Los Angeles.

husband $(p=0.01)$. The loneliness score was lower in patients who had been married longer and in those with higher incomes $(p<0.001 ; p=0.006)$. These patients indicated that they felt less lonely. The MSPSS score increased with the number of years of marriage and the increase was statistically significant $(p<0.005)$. This result suggests that those who were married longer felt they had more social support.

According to the results of the scales, 2 participants at high risk for depression (BDI scores of 39 and 23) and 4 with high anxiety scores were referred to the psychiatry clinic. Table 2 illustrates the mean values of the MSPSS and UCLA scale scores and the percentage over the mean. Table 3 demonstrates correlations between the scales.

\section{DISCUSSION}

In our study, the depression score of infertile women was lower than that seen in the general population. The mean anxiety score was found to be similar to that of the general population. Loneliness decreased with a longer marriage and greater monthly income $(p<0.05 ; p<0.05)$. The perception of social support also increased with the length of time married $(p<0.05)$. A total of 6 patients were referred to the psychiatry clinic based on their scores: 2 for depression and 4 for anxiety.

The relationship between infertility and depression has been investigated in many studies. The degree of depression, the need for treatment, the effects on infertility, and changes related to treatment vary between studies. It is noteworthy that factors such as social differences, family structure, marriage duration, monthly income, financial status, physical condition, social relationships, and social support status affect depression. ${ }^{[3-12]}$

In the most recent meta-analysis of these issues, Milazzo et al. ${ }^{[13]}$ investigated research on psychiatric problems in women with infertility. Women with a mood disorder have a birth rate that is significantly lower than their healthy peers. Psychological help is often needed to treat the negative psychological effects of unsuccessful infertility treatment. However, a causal relationship between depression and infertility has not yet been clarified.

Dural et al. ${ }^{[14]}$ demonstrated that the rate of depression is lower in infertile women with a high quality of life. A decreased quality of life has been shown to increase depression.

It is useful to emphasize that the rate of depression in women in our research group was lower than in the general population. However, in our research, the scales were completed during a face-to-face interview. This might have been a barrier for the participants to answer the questions comfortably. We also think that high rate of sharing with friends, the high degree of social support, cultural changes, and social differences may have been influential.

Depression and anxiety may differ between societies as well as between men and women. Madero et al. ${ }^{[15]}$ pointed out differences in anxiety and depression between societies and in couples in patients undergoing infertility treatment. They found that French individuals had significantly lower emotional and relational scores compared with Italians. Germans had higher social scores but lower relational scores than Italians. Men reported significantly lower anxiety scores than their female partners, and German couples 
reported lower anxiety and depression than their Italian counterparts.

It has been reported elsewhere that there were no significant increases in depression or anxiety in patients who were infertile. Biringer et al. ${ }^{[16]}$ found that women with current primary or current secondary infertility had a level of anxiety and depression not significantly different from mothers without infertility. Lakatos et al. ${ }^{[17]}$ determined that social and sexual concern, maternal relationship stress, and financial stress were significantly related to distress in women with fertility problems. Namdar et al. ${ }^{[18]}$ found that the general health of more than half of the infertile women studied indicated a degree of disorder and that they were at risk for anxiety, social dysfunction, and depression. Educational status, monthly income, and rural/ urban residency were major factors affecting the women's quality of life. The authors recommended performing case-control studies with larger sample sizes in different regions to better understand such effects.

In our study, it was determined that the level of anxiety among infertile women was similar to that of the general population. Of the participants, $49.6 \%$ had been treated for infertility before. This seems to be an important factor. Acceptance of the situation over time and a reduction in stress seems to lead to a decrease in anxiety.

Loneliness is the other important element in the status of these patients. It is well known that loneliness can contribute to psychiatric disorders. The frequency of loneliness in infertile patients has been a topic of discussion in recent years. Gokler et al. ${ }^{[9]}$ applied the UCLA Loneliness Scale to infertile women in Turkey and determined that there was no statistically significant difference $(p=0.283)$. They stated that the strong social relationships between people in the country might be important in this result. They also found no relationship between the duration of infertility and the level of loneliness. They concluded that this result may be due to the acceptance of infertility over time. In our study, the loneliness score was higher in those living with the husband's family $(p=0.01)$ and decreased with a longer marriage and higher monthly income $(p<0.05$; $p<0.05$ ). Social support is another issue that is thought to be important in this group of patients. Erdem et al. ${ }^{[10]}$ examined the MPSS scores of infertile women and found a lower depression rate in those who felt they had social support. The authors stated that social support is a preventive factor for depression. They also emphasized the importance of sharing with friends. In our research, it was observed that $92 \%$ reported that friends were a source of support. This high degree of social support is thought to be an explanatory factor in normal anxiety and loneliness scores.

There is not yet a clear treatment plan for infertile women with marked emotional changes, anxiety, feelings of loneli- ness, or depressive symptoms. Cunha et al. ${ }^{[19]}$ suggested that emotions could be managed through programs and therapy. Martins et al. ${ }^{[20]}$ reported that partner support was often found to be crucial in dealing with infertilityrelated psychological issues.

As a result of all these studies, it is understood that psychological changes in infertile patients vary according to societies and patient groups. Patients should be assessed individually to determine the appropriate approach.

\section{Conclusion}

We found that the financial circumstances, duration of marriage, and amount of social support influenced depression, anxiety, and loneliness in infertile patients. Since there was no significant difference in the levels of depression and anxiety in this group of patients in our society, we believe that professional support and treatment are only necessary when appropriate.

\section{Ethics Committee Approval}

The approval of the local Ethics Committee was obtained. Informed Consent

Approval was obtained from the patients.

Peer-review

Internally peer-reviewed.

Authorship Contributions

Concept: F.E., A.U.; Design: F.E., A.U.; Data collection \&/ or processing: F.E., A.D.A., B.T., D.M.C.; Analysis and/or interpretation: F.E., A.U., A.D.A.; Literature search: O.S., M.S.C.; Writing: O.S., M.S.C., E.S.; Critical review: O.S., E.S.

Conflict of Interest

None declared.

\section{REFERENCES}

1. Atasever M, Kalem MN, Hatırnaz Ş, Hatırnaz E, Kalem Z, Kalaylıoğlu Z. Factors affecting clinical pregnancy rates after IUI for the treatment of unexplained infertility and mild male subfertility. J Turk Ger Gynecol Assoc 2016;17:134-8. [CrossRef]

2. Su WJ, Cao ZY, Jiang CL. Inflammatory mechanism of depression and its new strategy for diagnosis and treatment. Sheng Li Xue Bao 2017;69:715-22.

3. Moeenizadeh M, Zarif H. The Efficacy of Well-Being Therapy for Depression in Infertile Women. Int J Fertil Steril 2017;10:363-70.

4. Omani Samani R, Maroufizadeh S, Navid B, Amini P. Locus of control, anxiety, and depression in infertile patients. Psychol Health Med 2017;22:44-50. [CrossRef]

5. Gdańska P, Drozdowicz-Jastrzębska E, Grzechocińska B, RadziwonZaleska M, Węgrzyn P, Wielgoś M. Anxiety and depression in women undergoing infertility treatment. Ginekol Pol 2017;88:109-12.

6. Donkor ES, Naab F, Kussiwaah DY. "I am anxious and desperate": psychological experiences of women with infertility in The Greater Accra Region, Ghana. Fertil Res Pract 2017;3:6. [CrossRef] 
7. Crawford NM, Hoff HS, Mersereau JE. Infertile women who screen positive for depression are less likely to initiate fertility treatments. Hum Reprod 2017;32:582-7. [CrossRef]

8. Henriksen J, Larsen ER, Mattisson C, Andersson NW. Loneliness, health and mortality. Epidemiol Psychiatr Sci 2017:1-6. [CrossRef]

9. Gokler ME, Unsal A, Arslantas D. The Prevalence of Infertility and Loneliness among Women Aged 18-49 Years Who Are Living in Semi-Rural Areas in Western Turkey. Int J Fertil Steril 2014;8:15562.

10. Erdem K, Ejder Apay S. A Sectional Study: The Relationship between Perceived Social Support and Depression in Turkish Infertile Women. Int J Fertil Steril 2014;8:303-14.

11. Oti-Boadi M, Oppong Asante K. Psychological health and religious coping of Ghanaian women with infertility. Biopsychosoc Med 2017;11:20. [CrossRef]

12. Du N, Zhou YL, Zhang X, Guo J, Sun XL. Do some anxiety disorders belong to the prodrome of bipolar disorder? A clinical study combining retrospective and prospective methods to analyse the relationship between anxiety disorder and bipolar disorder from the perspective of biorhythms. BMC Psychiatry 2017;17:351. [CrossRef]

13. Milazzo A, Mnatzaganian G, Elshaug AG, Hemphill SA, Hiller JE; Astute Health Study Group. Depression and Anxiety Outcomes Associated with Failed Assisted Reproductive Technologies: A Systematic Review and Meta-Analysis. PLoS One 2016;11:e165805.
14. Dural O, Yasa C, Keyif B, Celiksoy H, Demiral I, Yuksel Ozgor B, et al. Effect of infertility on quality of life of women: a validation study of the Turkish FertiQoL. Hum Fertil (Camb) 2016;19:186-91.

15. Madero S, Gameiro S, García D, Cirera D, Vassena R, Rodríguez A. Quality of life, anxiety and depression of German, Italian and French couples undergoing cross-border oocyte donation in Spain. Hum Reprod 2017;32:1862-70. [CrossRef]

16. Biringer E, Howard LM, Kessler U, Stewart R, Mykletun A. Is infertility really associated with higher levels of mental distress in the female population? Results from the North-Trøndelag Health Study and the Medical Birth Registry of Norway. J Psychosom Obstet Gynaecol 2015;36:38-45. [CrossRef]

17. Lakatos E, Szigeti JF, Ujma PP, Sexty R, Balog P. Anxiety and depression among infertile women: a cross-sectional survey from Hungary. BMC Womens Health 2017;17:48. [CrossRef]

18. Namdar A, Naghizadeh MM, Zamani M, Yaghmaei F, Sameni MH. Quality of life and general health of infertile women. Health Qual Life Outcomes 2017;15:139. [CrossRef]

19. Cunha M, Galhardo A, Pinto-Gouveia J. Experiential avoidance, selfcompassion, self-judgment and coping styles in infertility. Sex Reprod Healthc 2016;10:41-7. [CrossRef]

20. Martins MV, Peterson BD, Almeida V, Mesquita-Guimarães J, Costa ME. Dyadic dynamics of perceived social support in couples facing infertility. Hum Reprod 2014;29:83-9. [CrossRef]

\section{İnfertilitenin Kadının Psikososyal Yapısı Üzerine Etkilerinin Belirlenmesi}

Amaç: Bu çalışmanın amacı, toplumumuzdaki infertil kadınlarda depresyon, anksiyete, yalnızlık ve sosyal desteğin değerlendirilmesidir.

Gereç ve Yöntem: Haziran 20I2-Aralık 2012 tarihleri arasında hastanemiz infertilite kliniğine başvuran 140 hasta çalışmaya dâhil edildi. Tüm katılımcılar, Hamilton anksiyete, Beck depresyon, Kaliforniya Üniversitesi Los Angeles Yalnızlık (UCLA) ve Algılanan Sosyal Destek Destekli Çok Boyutlu Ölçek (MSPSS) formlarını doldurdu.

Bulgular: Depresyon skorlarının genel popülasyondan düşük olduğu tespit edildi. Anksiyete skorları popülasyona benzer oranlarda bulunmuştur. Yalnızlık ölçeği, evlilik yılının ve aylık gelirin artmasıyla azaldı $(p<0.05, p<0.05)$. Sosyal destek, evli olanların sayısının artmasıyla $\operatorname{artmıştır~}(p<0.05)$. Depresyon skalasına göre iki katılımcı ve kaygı ölçeğine göre dört katılımcı psikiyatri kliniğine sevk edildi.

Sonuç: Finansal durumların, evlilik süresinin ve sosyal desteğin infertil hastalarda depresyon, anksiyete ve yalnızlık puanları üzerinde etkili olduğunu düşünüyoruz. Bu hasta grubunda depresyon ve anksiyete arasında toplum geneline oranla bir fark olmadığı için, psikolojik destek ve tedavide yalnızca gerektiğinde yardım almanın uygun olduğuna inanıyoruz.

Anahtar Sözcükler: Anksiyete; depresyon; infertilite; sosyal destek; yalnızlık. 